2016

\title{
Islamic Law and Constitution-Making: The Authoritarian Temptation and the Arab Spring
}

Mohammad Fadel

University of Toronto - Faculty of Law, mohammad.fadel@utoronto.ca

Follow this and additional works at: http:// digitalcommons.osgoode.yorku.ca/olsrps

Part of the Islamic Studies Commons, Law and Society Commons, and the Religion Law Commons

\section{Recommended Citation}

Fadel, Mohammad, "Islamic Law and Constitution-Making: The Authoritarian Temptation and the Arab Spring" (2016). Osgoode Legal Studies Research Paper Series. 147.

http://digitalcommons.osgoode.yorku.ca/olsrps/147 


\section{OSGOODE HALL LAW SCHOOL \\ LEGAL STUDIES RESEARCH PAPER SERIES}

Research Paper No. 24

Volume 12, Issue 5, 2016

\section{Islamic Law and Constitution-Making: The Authoritarian Temptation and the Arab Spring Osgoode Hall Law Journal, Vol. 53(2), 2016, Forthcoming.}

Mohammad Fadel

This paper can be downloaded free of charge from: http://ssrn.com/abstract=2711859

Further information and a collection of publications from the Osgoode Hall Law School Legal Studies Research Paper Series can be found at:

http://www.ssrn.com/link/Osgoode-Hall-LEG.html

\section{Editors:}

Editor-in-Chief: Carys J. Craig (Associate Dean of Research \& Institutional Relations and Associate Professor, Osgoode Hall Law School, York University, Toronto)

Production Editor: Kiana Blake (Osgoode Hall Law School, York University, Toronto) 
Osgoode Legal Studies Research Paper No. 24

Vol. 12/ Issue. 5/ (2016)

\title{
Islamic Law and Constitution-Making: The Authoritarian Temptation and the Arab Spring
}

Osgoode Hall Law Journal, Vol. 53(2), 2016, Forthcoming.

Mohammad Fadel

\begin{abstract}
:
The political dynamics that have characterized post-Mubarak Egypt have often been understood to be a battle between "religious" forces, represented by the Muslim Brotherhood and its supporters, and "secularist" forces, represented by a diverse group of civil society actors. Opposition of this latter group to the "religious" politics of the Muslim Brotherhood is therefore understood to be the primary cause of the events that led to the July 3, 2013 military coup that overthrew Egypt's only freely elected President, Mohammed Morsi. Without denying the salience of a religious-secularist divide in Egypt, this narrative of post-Mubarak politics fails to appreciate the importance of intra-Muslim religious division regarding the proper place of Islam in the Egyptian political order, and its relationship to the state. This paper argues that traditionalist Egyptian religious scholars have a normative commitment to political authoritarianism that is tied to their understanding that the only proper modes of religious instruction is through adherence to a tradition of learning, and a conception of religion as something that exists outside of, but ultimately, is responsible for directing the state through the cooperation of the pious autocrat. The Muslim Brotherhood, and their supporters, on the other hand, view religious authority as a kind of resource that any person can acquire with sufficient diligence, and accordingly, can be incorporated within a democratic polity by cultivating a religiouslyminded citizenry. I trace the normative resources for both positions in the Sunni tradition and then illustrate why those debates can cast light on the important political differences between the Muslim Brotherhood and the Azhar, even though they may be in agreement on a broad array of substantive questions.
\end{abstract}

\section{Keywords:}

"Republican Islam"; "traditionalist Islam"; "Muslim Brotherhood"; "al-Azhar"; "al-Ghazali"; "al-Mawardi"; "Islamic modernism"; "Islamic constitutionalism"

\author{
Author(s): \\ Mohammad Fadel \\ University of Toronto \\ E:
}




\author{
Islamic Law and Constitution-Making: \\ The Authoritarian Temptation and the Arab Spring \\ Mohammad Fadel
}

Associate Professor and Canada Research Chair for the Law and Economics of Islamic Law University of Toronto Faculty of Law

When 'Abd al-Fattah al-Sisi, then the Egyptian Defense Minister, announced that the Egyptian military had removed Egypt's first democratically-elected President, Mohamed Morsi, he was flanked by the heads of Egypt's twin religious establishments - the Shaykh of al-Azhar, Ahmad al-Tayyib, and the Pope of Coptic Church, Tawadrus II - and the head of the ultra-conservative Salafist religious party, Yasir Burhami. The sight of these religious heavyweights at the side of the military strongman and other senior members of Egypt's armed forces announcing a coup against a democratically-elected president who himself represented a religious-political social movement - the Muslim Brotherhood - might come as something of a surprise to those observers of Egyptian politics who had reduced post-Mubarak political conflict to a struggle between theocrats and secular democrats. The symbolism of the July 3 coup, as well as subsequent developments in post-Morsi Egypt, both make clear that contesting theocratic conceptions of religion and state are as much at stake as an alleged conflict between secular democracy, on the one hand, and theocracy, on the other. One of these theocratic conceptions vests the people with the responsibility for articulating and implementing divine law, while the other vests this power in a paternalistic condominium between the holders of coercive power and the possessors of religious authority.

When discussing the phenomenon of what has come to be termed "political Islam," commentators have generally been most interested in exploring the political thought of groups such as the Muslim Brotherhood, whose politics, while theocratic, also aspires to certain republican ideals of self-government, broad-based participation, and establishing accountability through competitive elections. ${ }^{1}$ Far less attention, however, has been paid to the continued vitality of traditionalist conceptions of religion and politics in Sunni thought, particularly in the context of the official religious establishments found in various Muslim-majority states. This oversight is particularly damaging to our understanding of the relationship of religion to the state in Egypt, where the state nationalized the

1 See, for example, Carrie Rosefsky Wickham, The Muslim Brotherhood: Evolution of an Islamist Movement (Princeton: Princeton University Press, 2013); Jeffrey R. Halverson, Theology and Creed in Sunni Islam (New York: Palgrave-MacMillan, 2010), p. 75 (attributing to a leader of the Egyptian Muslim Brotherhood in the 1980s the view that "Islamic government is, in fact, a civil government that depends on the consent and support of the people"); see generally, Chapters 3 \& 4. This is of course not to say that the Muslim Brotherhood has an internally coherent view on democracy, even one within an explicitly Islamic reference. Wickham's discussion of the contradictions that the embrace of party politics in the 1980s imposed upon the Brotherhood in Chapter 3 of her book is especially helpful in highlighting the internal divisions between the Muslim Brothers over whether their role is purely one of religious teaching (da'wa) or that of a political party. 
institution of al-Azhar and expanded it in an attempt to appropriate religion as a tool for governance. ${ }^{2}$ The intellectual bias of political scientists, theorists and lawyers toward groups like the Muslim Brotherhood, which are the product of modernizing reformist movements, at the expense of the political thought of establishment religious intellectuals, may very well be the reflection of the modern conceit that Muslim religious modernists are destined to triumph over religious traditionalists, all as part of an inevitable march toward a more liberal (and secular) future.

In short, the battle that is currently playing out in Egypt is not only between those who would like to a see a secular Egypt in contrast to a more religious one, but it is also, and maybe even primarily, a battle between different conceptions of the relationship of religion to the state: a battle between a "republican" form of Islam and a "traditionalist" form of Islam that is sympathetic to authoritarian politics. Differences between what I am calling "republican" Islam and "traditionalist" Islam do not necessarily translate into sharp differences regarding the content of what it means to be an observant Muslim in the modern world, or even the degree of rigor in religious practice; rather, their disagreement arises largely in domains such as the proper mode by which religious knowledge is to be acquired and their affective dispositions to the tradition itself. For traditionalist Islam, then, it is not sufficient for one to hold the correct beliefs, and practice outwardly Islamic rituals in the proper sense; one must also acquire one's knowledge of authoritative doctrine and practice from a teacher who is himself wellgrounded in the "tradition" through an established chain of teachers, real or imagined, going all the way back to the Prophet of Islam (ideally at least). Tradition is indispensable to the acquisition of religious knowledge and virtues from this perspective because the mastery of religious values emerges through a process of acculturation (tarbiya) which enables novices to embody those values. This process of acculturation is distinct from, and transcends intellectual cognition (' $\mathrm{i} / \mathrm{m}$ ) of religious truth. ${ }^{3}$ While religious truth may be a proper subject of instruction ( $\mathrm{ta}$ ' $\mathrm{lim}$ ), mere instruction, without reliable teachers who properly embody Islamic teachings, cannot produce properly acculturated religious subjects. ${ }^{4}$ For this reason, what I am calling "traditionalist" Islam continues to place great emphasis on Sufism, sometimes called Islamic mysticism, because of the belief that the institutions and practices that Sufism cultivates, including the hierarchical relationship between the teacher ( $a$ l-shaykh) and the

$2 \quad$ Malika Zeghal, "Religious Education in Tunisia and Egypt: Contrasting the Post-Colonial Reforms of AlAzhar and the Zaytuna," in Trajectories of Education in the Arab World: Legacies and Challenges 115-116 (Osama Abi-Mershed ed., 2010).

3 Tarbiya is the verbal noun from the verb rabbā, which means "to rear, nurture," while ta līm is the verbal noun from the verb 'allama, which means "to teach, instruct." The object of what is taught is called 'ilm, which means "science" or "knowledge." Knowledge is simply a product of propositional reasoning, and does not, on its own, lead to certain embodied virtues.

$4 \quad$ See, for example, Instruction of the Student: the Method of Learning, Burhān al-Dīn al-Zarnūjī, translated by G.E. von Grunebaum \& Theodora M. Abel (Starlach Press, 2003, $2^{\text {nd }}$ revised edition), pp. 13-17. Hamza Yūsuf, an American convert to Islam and a leading US traditionalist Muslim theologian, expresses support for the notion that proper Islamic education is dependent upon immersion in tradition when he wrote in the forward to this translation, "We are indeed spiritual and intellectual children, and until we mature through learning and mastering our own tradition, we can not safely trust ourselves to delve into primary texts for other than blessings and moral guidance." Ibid., p. ix. 
student (al-murīd), are indispensable in the production of a properly embodied practice of Islam. Under the traditionalist conception, then, individuals lack the independent capacity to achieve virtue and need assistance from others in order to enable them to live virtuous lives, a position that generates sympathy for authoritarian rule, at least if it is appropriately pious.

What I am calling "republican" Islam does not deny the traditionalist difference between embodiment of religion and intellectual cognition of its truth, but it denies the necessity of tradition as a pre-condition for embodying Islamic religious values. It believes that any properly motivated Muslim who has sufficient intellectual skills may study the basic sources of Islam independently and obtain an adequate degree of religious knowledge and virtue. "Republican" Islam, however, is not constituted by a particular stance toward the Islamic tradition; however, it is consistent both with a healthy respect for the intellectual content of the tradition, and with complete indifference or even hostility to that tradition. What unites "republican" Islam is simply the proposition that the "tradition" is not necessary for living as a good Muslim in the modern world. The potential for each person independently to acquire an adequate conception of Islamic virtue and manifest it without the need for authoritative teachers recognizes each person as a potentially self-governing virtuous actor, and this is what gives this conception of Islam its republican disposition.

While it would be an error to assume that the positions articulated in this contemporary debate in Egypt are simply a recapitulation of medieval debates on the relationship of religion to political ordering, both lines of debate can plausibly lay claim to parts of the long tradition of Islamic political thought. Given the depth of support among traditionalist theologians for the coup in Egypt, more attention should be given to these non-republican, authoritarian forms of political Islam. This paper attempts to address this gap in the literature by considering arguments in Sunni Islam that might cause traditionalist theocrats to favor authoritarianism over a republican form of theocracy. Part I of the paper will provide a brief overview of normative constitutional theory in Sunni thought. Part II will introduce Sunni conceptions of non-normative, emergency rule, how they relate to the normative Sunni legal order and how emergency rule provided for the development of a quasi-Platonic philosophical theory of religion and the state that helped justify a hierarchical, indeed, authoritarian political order. Part III discusses Islamic modernism as an attempt to restore normative constitutional rule against a state of emergency. Part IV will then apply this framework to the current religious divides by focusing on the positions taken by two-well regarded representatives of each tradition toward the Egyptian Revolution of 2011 and the military coup of 2013, Yūsuf al-Qaraḍāwī, for the "republican" camp, and 'Alī Jumu'a, for the authoritarian camp. ${ }^{5}$ Part $V$ will discuss the passage of the Șukūk Law, a law passed during the brief tenure of the deposed President Morsi, which authorized the state to issue bonds in conformity with Islamic law, and the reluctance of the Muslim Brotherhood to involve the senior

$5 \quad$ A full treatment of the authoritarian Islam camp would include a treatment of the extreme right-wing Salafi movement, whose leader Yasir Burhami, also supported the coup. Space limitations, however, preclude specific treatment of Salafi political thought. For an essay exploring the relationship of contemporary Salafi political thought to democracy, and why they supported the coup, see Jonathan Brown, "The Rise and Fall of the Salafi al-Nour Party in Egypt," November 14, 2013, Jadaliyya, available at http://www.jadaliyya.com/pages/index/15113/the-rise-and-fall-of-the-salafi-al-nour-party-in-e\#_ftn4 (last viewed, March 4, 2015). 
theologians of the Azhar in the law making process. This incident, I suggest, brings into sharp relief the different models of Islam and the state: one, advocated by the Muslim Brothers and its supporters, that believes that a representative state is the best interpreter of Islamic law, and the other, represented by scholars like 'Alī Jumu'a, which believes that Islamic law is best articulated by a specialized body that exists above and outside the state. The paper will then conclude.

\section{Normative Sunnī Constitutional Theory}

Normative Sunni constitutional theory is comprised of the rules governing the caliphate, including, the rules governing the selection of the caliph, the powers he exercises and the manner by which those powers may be exercised, and the rules governing the establishment of lesser offices, their powers, and how those powers may be exercised. In Sunni theology, the caliph, although he is a successor to the Prophet Muhammad, lacks prophetic authority. Instead, he is charged with protecting the worldly interests of the Muslim community. Alongside the secular duties of defending the frontiers, collecting and distributing taxes, upholding justice, making appointments of lesser public officials, e.g., regional governors and judges, and construction of public works, the caliph was also responsible for protecting religious orthodoxy against both non-Muslim enemies of the Muslim community and heretical Muslims whose heterodox belief undermine true religion. ${ }^{6}$

In Sunnī constitutional theory, appointment of a caliph is an obligation on the entirety of the Muslim community (fard kifāya), and is understood to be a contract ('aqd) between the community and the duly appointed candidate. The duty is discharged pursuant to a deliberative process involving a group of electors, known as ahl al-hall wa'l-'aqd, "those who loosen and bind." These individuals are entrusted with selecting an appropriate candidate for the office in accordance with the requirements Islamic law imposed on the office and in light of the community's particular circumstances at the time of the selection. Alternatively, the incumbent caliph was authorized to act as the sole elector and designate his successor (wali al-'ahd) during the incumbent's lifetime. In both cases, once the electors settled on a candidate for the office, or the incumbent caliph selected a successor, the electors, or the incumbent caliph, as applicable, extended an offer to the selected candidate to accept the duties of the office. Only upon the candidate's acceptance of the offer is the contract concluded, and the communal duty to appoint a caliph discharged. ${ }^{7}$

In both scenarios, Islamic law understood the electors and the incumbent caliph to be acting in a representative - not a personal - capacity on behalf of the Muslim community as a whole. Thus, they were not permitted to select a candidate based on personal preferences; rather, they were entrusted to

$6 \quad$ Mohammad Fadel, "Back to the Future: the Paradoxical Revival of Aspirations for an Islamic State," 14,1 Review of Constitutional Studies 105, 109-13 (2009) (giving an overview of the Sunnī theory of legitimate government). For a more thorough account of the normative Sunni conception of the state, see Mohammad Fadel, "Islamic Law Reform: Between Reinterpretation and Democracy - Neal Coulson Memorial Lecture School of Oriental and African Studies," 18 Yearbook of Islamic and Middle Eastern Law (forthcoming).

7 Al-Māwardī, The Ordinances of Government: a Translation of Al-Aḥkām al-Sulțāniyya w'al-Wilāyāt alDiniyya, translated by Wafaa H. Wahba (Reading, UK: Center for Muslim Contribution to Civilization; London : Garnet Publishing LImited, 1996), Chapter 1. 
use their discretion to pick the most appropriate candidate in light of the requirements imposed by the law and the best interests of the community at the time of the election. The electors were not permitted to change their minds and depose the incumbent caliph unless the caliph breached the contract by which he became caliph. So too, the incumbent caliph was not permitted to dismiss a duly appointed successor in the absence of legal cause. In each case, Muslim jurists reasoned that the authority used by the electors to appoint the caliph, or by the caliph to designate a successor, was limited to discharging the right of the community to see that the office of the caliph was duly filled. Once that obligation was discharged, the electors, or the caliph, as applicable, were divested of any authority they might have until such time as the law re-authorized them, e.g., if the caliph commits a material breach of the contract and loses the right to continue in office, or if the designated successor becomes physically or legally incapable of fulfilling the terms of the office. ${ }^{8}$

The representative capacity of the electors and the caliph in the process by which caliphs are selected is part of a broader Sunni understanding that the caliph - and by extension all public offices are representatives of the Muslim community, and that their authority is dependent upon contractual delegation and not inherent personal authority, whether understood as coming from God or good fortune. In normative Sunnī legal theory, then, all public officials exercised powers pursuant to a proper delegation: the caliph is appointed as a representative of the public, and he then delegates various powers to lesser officials, with each official's authority being limited to the terms set out in the relevant act of delegation. The representative rather than personal character of the caliph's authority, and the authority of other public offices, is confirmed in various discussions on the jurisdiction of public officials, and whether they terminate upon the death or dismissal of the relevant appointing official. Jurists, for example, carefully distinguished between public officials who were personal delegates of the caliph, such as ministers, and public officials, such as regional governors and judge, who were delegates of the public. The class of officials who are personal delegates of the caliph are automatically divested of their offices upon the death or removal of the caliph who appointed them, while officials who were deemed to be delegates of the public continued in office, even after the caliph who appointed them died or was removed from office. ${ }^{9}$

The contract of the caliph, because of its representative character, imposed upon the caliph, and other public officials, the duties of a fiduciary. The fiduciary nature of the powers that the caliph - and by extension, other public officials - enjoys is manifested expressly in the term used to describe the caliph's designated successor: wali al-'ahd, the holder of the covenant. ${ }^{10}$ "The covenant" itself is that of

$8 \quad$ lbid., p. 110 n. 21.

9 See, for example, Abū al-Ḥasan 'Alī b. Muḥammad b. Ḥabīb al-Māwardī, al-Ahkām al-Sulțāniyya (Beirut: Dār al-Kutub al-'Ilmiyya, n.d.), p. 37 (distinguishing between a governor who was appointed by the caliph, whose appointment survives the appointing caliph's death, and a governor appointed by the caliph's prime minister, whose appointment comes to an end with the death of the prime minister, because the caliph's appointments are in "right of the Muslims (niyāba 'an al-musliminn)" while the appointments of the prime minister are in "right of himself (niyāba 'an nafsihi)." 
the Muslim community and entails that the Muslim community entrusts the ruler and the public officials he appoints to use the powers delegated to them for the good of the community and not their own personal good. The fiduciary character of the power exercised by public officials in turn creates a duty of obedience on the part of the Muslim community. Accordingly, the contractual basis of public office, which creates a principal-agent relationship between the ruler (and other public officials) and the Muslim community, combined with the fiduciary powers of public officials over the affairs of the Muslim community, provide two alternative, but mutually reinforcing, moral grounds that limit the power of public officials while simultaneously justifying the duty of obedience to the public order on the part of the public. ${ }^{11}$

\section{Non-Ideal Sunni Constitutional Theory}

In an ideally constituted Sunnī state, the caliph sits atop the public order, having been duly selected by electors, acting in good faith for the public good, or after having been appointed by the previous caliph who, after diligently considering all possible candidates, selected his successor in accordance with the law and the best interests of the community. So too, lesser officials - governors, judges, market inspectors, generals, tax collectors, etc. - are also appointed, based on the legal requirements established for their respective offices, which include knowledge of applicable substantive law and possession of an adequate degree of personal integrity. All public officials, from the caliph to the lowliest tax collector, moreover, know the substantive law that applies to the exercise of their powers, and dutifully follow its requirements; moreover, they are careful to refrain from exceeding the territorial and substantive limitations of their jurisdiction, which are spelled out in the terms of their appointment.

This ideal description of the Sunnī constitutional order suggests a conception of public order that is wholly indifferent to questions of power, and in certain respects, one could say, at a minimum, that Sunni theologians and jurists aspired to establish a public order that was justified entirely by reference to legal norms. It is perhaps this tendency of Sunnī constitutional thought that Orientalist historians had in mind when they referred, often derisively, to Sunnī constitutional law as expressing a utopian ideal that was disconnected to the actual circumstances of historical Muslim states.

It would be a mistake, however, to think that ideal Sunni theory was completely indifferent to questions of power. Two of the earliest comprehensive legal treatments of the caliphate both include the requirement that the successful candidate for the caliphate possess martial qualities that gives him effective power, not only to deter external enemies, but also to uphold and defend the public order. ${ }^{12}$ Unlike the other legal requirements such as learning, integrity and physical fitness, the requirement of effective power - with the political and martial qualities implicit in that requirement - was not

$11 \quad$ Fadel, p. 111 n. 22.

12 Al-Māwardī, p. 6 (courage and boldness for the confrontation of external and internal threats) and Abū Ya 'lā Muḥammad b. al-Ḥusayn al-Farrā', al-Aḥkām al-Sulțāniyya (Beirut: Dār al-Kutub al-'Ilmiyya, 1983), p. 20 (successful candidate must be competent in military and political affairs and capable of defending the community). 
something that could be presently ascertained in any particular candidate. At best, it could be hoped that the nominee would turn out to enjoy the functional attributes that were demanded of the caliph.

The ability to wield effective power introduced an element of political realism into Sunnī constitutional thought that was otherwise overwhelmingly legalistic in its outlook on public law. As a practical matter, this manifested itself in the recognition of jurisdiction by acquisition (imārat al-istīlā'), rather than delegation. ${ }^{13}$ Under the terms of the ideal Sunni constitution, the caliph is responsible for the public order in its entirety, appointing and dismissing public officials, including regional governors, in the good faith exercise of his discretion. What happens, however, if the caliph lacks effective power to enforce his decisions, or if a local politician, who himself might be a military commander or in alliance with a local military commander, seizes the apparatus of the government without the caliph's prior consent? In such a circumstance, the local politician is acting without right and therefore is a rebel insofar as he is acting in defiance of the public order represented by the caliph. If, however, the usurper is prepared to acknowledge the legitimacy of the public order, and to uphold it, including, by recognizing the caliph, Muslim jurists were prepared to legitimate the rebel's position through an ex post process known as ratification of jurisdiction (tașhịh al-wilāya). This was justified on the functional grounds of the public welfare: insofar as the rebel was prepared to lay down his arms and uphold the public order, the public good would be better served by re-establishing peace and stability rather than engage in further conflict that would undermine the interests of the local community affected. ${ }^{14}$

But the recognition of usurpers on functional grounds was not the most crucial channel through which the spectre of violence entered into the constitutional order. Although there was an ideal that the caliph should be appointed through the consent of the community as represented by the electors' deliberations, pre-modern jurists never provided a conclusive procedural means for determining how many electors needed to support a candidate in order for that candidate to be selected as caliph. AlMāwardī, for example, reported various positions on the minimum amount of support a successful caliph required, with some theologians and jurists holding that the selection of a suitable candidate by even one elector was sufficient for the contract to be constituted. This position was allegedly based on historical precedents from the early Muslim community when it was little more than a city-state in western Arabia, but the indeterminacy of the role and number of electors needed to select a caliph also served an important functional purpose: to classify combatants as either supporters of the legitimate order, or rebels that could be legitimately targeted and killed so long as they defy the legitimate order.

The division between supporters of the legitimate order and rebels was derivative of the Sunni notion that formation of the public order was itself obligatory, and once that obligation was discharged, all Muslims were under an obligation to submit to that authority. It thus followed that those who refused to recognize the putative caliph by, for example, recognizing another ruler in whose name taxes were collected, judges were appointed, and judicial verdicts enforced, were legally rebels - at least from

$13 \quad$ Al-Māwardī, pp. 39-40.

$14 \quad$ Ibid. 
the perspective of those who recognized the putative caliph - and could be legitimately fought. ${ }^{15} \mathrm{Al}^{-}$ Māwārdī's contemporary, the Hanbali jurist al-Farrā', recognized that a consent-based theory of the state, if taken seriously, would require that the successful candidate garner the choice of the vast majority (al-jumhür) of the electors. ${ }^{16}$ In the absence of such a candidate, the successful candidate will inevitably be the one who conquers and subdues (qahr) his rivals, with each one of them, until the moment he is defeated (and thus shown to be a pretender), having a colorable claim to be caliph. ${ }^{17}$ For Farrā', then, consent, as the basis for appointing the caliph, even if it is an aspirational ideal, was, as a practical matter, utopian. The real basis of the ruler's authority was his effective ability to subdue his rivals. Al-Ghazālī, a leading jurist in the generation following Māwardī and Farrā', proposed to resolve the contradiction between consent and power by reaffirming Māwardī's contention that the consent of the electors was crucial, but incorporating Farrā's critique of the consent-based theory by specifying that it was not the consent of a pre-determined number of electors that made the appointment effective, but rather the candidate's success in receiving the support of those electors, e.g., military leaders, who could provide the candidate with the effective power (shawka) to discharge the functions of the caliph. ${ }^{18}$

The solution proposed by Ghazali has been described as resulting in an effective separation of the secular, worldly aspects of governance - which would become the responsibility of the holders of effective coercive power, i.e. the military - and the religious aspects of governance, e.g., maintenance of courts, supervision of public rituals, etc., which would remain the responsibility of the caliph, and the religious officials he appointed to fill largely religious posts. ${ }^{19}$ In this scheme, the religious class was to act as the advisors to the holders of power by teaching them the requirements of justice through instruction in Islamic law. The military class, if only out of self-interest, would uphold the requirements of the law because it understood that the economic foundations of their power depended upon

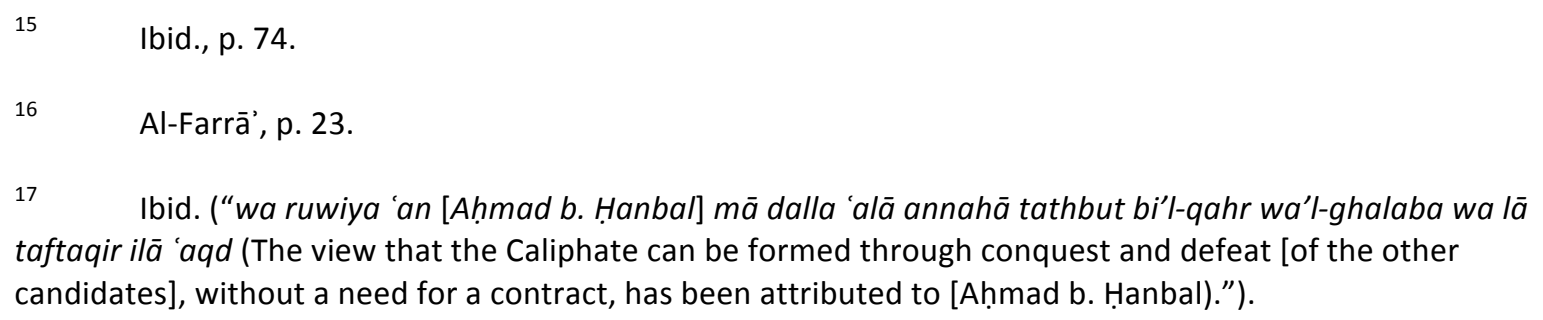

18 Richard Joseph McCarthy, Freedom and Fulfillment: an Annotated Translation of al-Ghazālī's al-Munqidh min al-Ḍalāl and other Relevant Works of al-Ghazālī (Boston: Twayne Publishers, 1980), p. 277. Al-Ghazālī also asserted that the means by which social choice settles on a single candidate is never, and can never be, the product solely of human choice. Rather, God's choice manifests itself through the dynamics of social power that settles on the successful candidate. Ibid. 49. 
maintaining a basic system of justice, a theory popularly known as "the circle of justice," and popularized through numerous hortatory works written by the scholarly class to the rulers of their day. ${ }^{20}$

Al-Ghazālī, however, did more than offer a reconciliation of the normative elements of the caliphate with its realistic elements; he also offered a philosophical account of politics that justified a dualistic polity, one that separated its symbolic/normative order from its coercive order, and arranged the various classes of society hierarchically. Accordingly, he posited four different kinds of politics: prophetic; princely; rational; and, affective. ${ }^{21}$ This taxonomy of the modes of political life was itself dependent upon other conceptions, such as the social division between the elite (al-khāssșa) and the commoners ( $a l-\bar{a} m m a)$, and a radical disjuncture between the rational capacities of each group. Prophetic politics was the highest mode of politics according to al-Ghazāli because it, uniquely among the four modes of politics, exercised universal jurisdiction, governing the political and the moral, and the elite and the commoners. Princely politics was similar to prophetic politics insofar as it exercised universal jurisdiction over the elite and the commoners, but it was ultimately inferior to it on Ghazali's account because it had jurisdiction only over the outward aspects (zāhir) of people's lives, not their inner moral life (bāțin). Unlike prophetic politics, which unified power with rationality and morality, princely politics enjoys only the outward power of coercion, without any authority over the moral lives of either the elite or the commoners.

In the absence of prophetic politics, religious scholars, saints and philosophers are entrusted with the government of the moral life of the elite, while preachers and jurists were entrusted with the government of the moral life of commoners. The moral government of the elite is based on rational argument and demonstration, while that of commoners, because they are incapable of understanding rational argumentation, is vested in preachers who use affective rhetoric, rooted in imagination, to motivate the masses to virtue. Because of the impossibility in Islamic dogma of prophetic politics following the death of the Prophet Muhammad, it is not surprising that Ghazāli concludes that the noblest kind of post-prophetic politics is that pursued by saints, philosophers and religious scholars who, unlike other classes of society, pursue the good solely for its own sake. ${ }^{22}$ The ruling class, on the other hand, although they are capable of understanding rational demonstration, are in fact moved by honorthe love of praise and the fear of blame - and not the pursuit of the good for itself. What this means, however, is that they can practically live good lives if their conceptions of honor and dishonor are truthful, which will be the case when their conceptions of honor are derived from the teachings of the religious-philosophical elite. ${ }^{23}$ The masses, however, are moved only by the desire for pleasure and the

20 For a description of the circle of justice, see Wael Hallaq, Shari a: Theory, Practice and Transformation (New York: Cambridge, 2009), pp. 199-200.

21 Abū Ḥāmid Muḥammad b. Muḥammad al-Ghazālī, Mīzān al-'Amal, ed. Sulaymān Dunyā (Cairo: Dār alMa'ārif, 1964), p. 329.

22 Ibid., pp. $287-88$.

$23 \quad$ Ibid 
fear of pain, and accordingly, they must be controlled by law, which is primarily a means for restraining their passion (shahwa). ${ }^{24}$

Ghazālī's taxonomy of the various kinds of politics in turn derived from his tripartite conception of the soul's powers, his conception of justice as the proper ordering of these powers, and the justice of the polity being a macrocosm of the microcosm of justice in an individual. In Ghazali's psychology, the soul has three different powers, the intellectual (al-tafakkur), the spirited (al-ghadab), and the animal $\left(a l\right.$-shahwa). ${ }^{25}$ Justice is not an independent virtue, but is rather a condition (hāl) that is achieved when the three parts of the soul are ordered appropriately according to a natural hierarchy with the intellectual at the apex, the spirited in the middle, and the animal at the bottom. ${ }^{26}$ A person is just, then, when his rational power is in control of his spirited and animal powers. ${ }^{27}$

Ghazâli applied this tripartite conception of the soul's powers to understand the political life of the polis (al-madina), which is also made up of three different classes: classes that are served by others, classes that serve and are served, and classes that only serve others. Justice, in the case of the polis, as it is in the case of the individual, is a problem of proper ordering: it exists when the relationship of the various social classes is maintained according to their natural hierarchical order.

"Justice in politics, as we have mentioned in our discussion of the powers of the soul, is attained when the different parts of the city are arranged in the fashion that imitates the parts of the soul such that the city becomes, with respect to its harmony, the relationship of its constituent parts, and the cooperation of its various elements, in accordance with the purpose of living together, like a single body. Each thing, therefore, must be placed where it belongs. Its residents are divided [into three classes]: the first, which is served, but does not serve [others]; the second, which serves and is not served [by others]; and, the third, a group which serves [others] in certain respects, and is served [by others] in other respects." 28

\section{$24 \quad$ Ibid.}

$25 \quad$ Ibid., pp. 232-33.

26 Ibid., p. 272 (wa ammā al- 'adl fa-huwa ḥāla li'l-quwā al-thalāth fí-ntiẓāmihā 'alā al-tanāsub bi-ḥasab altartīb al-wājib fíl-isti '(a' 'wa'l-inqiyād).

$27 \quad$ Ibid., p. 234 (wa mahmā așlahat al-quwā al-thalāth wa dụițat 'alā al-wajh alladhī yanbaghī wa ilā alhadd alladhī yanbaghī wa ju 'ilat al-quwwatān munqādatayni li'l-thālitha allatī hiya al-fikriyya al-'aqliyya fa-qad hașalat al-'adāla).

28 Ibid., p. 273 (wa'l- 'adl fíl-siyāsa an turattaba ajzā' al-madīna al-tartīb al-mushākil li-tartīb ajzā' al-nafs hattā takūna al-madīna fí'-'tilāfihā wa tanāsubi ajzā'ihā wa ta'āwun arkānihā 'alā al-gharaḍ al-mațlūb min alijtimā' ka'l-shakhṣ al-wāḥid fa-yūọa 'kull shay' fĩ mawḍi ihi wa yanqasim sukkānuhu ilā makhdūm lā yakhdim wa ilā khādim laysa bi-makhdūm wa ilā țabaqa yakhdimūna min wajh wa yukhdamūna min wajh). 
Justice in the city becomes manifest, therefore, when the ruler is wise and overpowering (bașiran qāhiran), the soldiery is mighty and obeyed (dhi quwwa wa țā $a$ ), and the masses are weak and submissive (ḍu'afā' salsā al-inqiyād). ${ }^{29}$

The analogy of the parts of the city to the parts of the soul is not perfect, however, as Ghazāi depicts the political class - the rulers (saläțin) and well-regarded men of society - as having only juvenile command of their reason ( $a l$ - 'aql al-qāșir), being regarded as rational only in relation to the plainly irrational masses. The true possessors of perfected reason ( $k a m \bar{a} / \mathrm{l}$ l- ' $a q l)$ are the saints, scholars and philosophers (awliyā' wa hukamā' wa muhaqqiqī al-'uqalā'). The political hierarchy reflects each class's relative perfection of its reason: the masses occupy the lowest rung of society because they are motivated solely by their animal powers (al-shahwa) and their desire for pleasure and their revulsion at pain. Worldly rulers, and the other well-regarded men of society, are motivated by honor, the love of praise and the fear of blame from their peers. It is only the third group - the saints, the scholars and the philosophers - who desire the good for the sake of the good, and thus can be said to have perfected reason. ${ }^{30}$ As such, Ghazāli seems to argue, justice requires that they be the legislators for society, and indeed, that is the role he prescribes for them: to provide rulers with the precepts necessary to establish a just order. ${ }^{31}$ Accordingly, he urges rulers to love scholars and heed their advice, making this the second of his ten foundational principles of justice. ${ }^{32}$ Given Ghazālì's essentially hierarchical conception of justice, it is not surprising that he states that the ruler is chosen by God, and for this reason, the people are under an obligation to love him, obey him and not resist him. ${ }^{33}$ The ruler's moral obligation is to show gratitude to God by discharging his duties as ruler diligently, humbly and sincerely. ${ }^{34}$ Ghazālī's political thought, instead of conceiving the ideal ruler as the ideal agent, conceives of him as the ideal autocrat: rational, pious and strong.

Ghazali is often recognized as the theoretical architect of the sultanate as the distinctive Islamic institution of governance dominating the late Islamic Middle Ages and Early Modernity. Although the sultanate was never recognized by the jurists as a distinct legal institution (all holders of public office

$\begin{array}{ll}29 & \text { Ibid., pp. } 272 . \\ 30 & \text { Ibid., p. 287-88. }\end{array}$

$31 \quad$ Nabih Amin Faris, The Book of Knowledge, being a translation with notes of the Kitāb al-'Ilm of alGhazzālī's Iḥyā' 'Ulūm al-Dīn (Lahore: Sh. Muhammad Ashraf, P. 33 ("[The jurist] become the teacher of the magistrates and their guide in government and control, that through their righteousness the affairs of men in this world may be set in order.").

32 Abū Hāmid Muḥammad b. Muḥammad al-Ghazālī, al-Tibr al-Masbūk fí Nașāiḥ al-Mulūk, edited by Aḥmad Shams al-Dīn (Beirut: Dar al-Kutub al-'llmiyya, 1988), p. 18.

33 Ibid., p. 43 (fa-yanbaghī an yu 'lama anna man a'țāhu allāhu darajat al-mulūk wa ja 'alahu żillahu fíl-arḍ fa-innahu yajib 'alā al-khalq mahabbatuhu wa yalzamuhum mutāba'atuhu wa țā'atuhu wa lā yajūz lahum ma șiyatuhu wa munāza'atuhu).

34

Ibid., pp. 14-8. 
from the earliest periods of Islamic law were designated with the title sulțān), ${ }^{35}$ jurists increasingly recognized the legitimacy of rule through the fact of acquisition. Post-Ghazāii Mamluk-era Shāfi'i jurists, such as the well-known and much maligned Badr al-Dīn Ibn Jamā'a, openly stated that conquest was a means for the establishment of government, and conquest came to be a third method for assumption of the caliphate in authoritative Shāfi i manuals of positive law. ${ }^{36}$ While statements such of modern commentators such as H.A.R. Gibb and Noel Coulson that these concessions to de facto power amounted to an abandonment of the legal norms of the shari'a in favor of a "secular absolutism" ${ }^{37}$ can be dismissed as hyperbolic, it is certainly true that Sunni jurists by the $14^{\text {th }}$ century had acquiesced to the legitimacy of ascension to rule through the force of arms, and instead of contesting the means by which officials came to hold power, they invested their legitimating resources into influencing how de facto power holders exercised their power. The waning of interest in the contractual legitimacy of rulers was further accelerated by the rise of the quasi-Platonic philosophical conception of the just polity such as those articulated by Ghazâlī. The contractual tradition of legitimacy, however, would be resurrected in the $19^{\text {th }}$ century, with the rise of Muslim modernism. We now turn to this topic.

3. Islamic Modernism, anti-Despotism, and the Ideal of Popular Participation in Government

This division of labor, pursuant to which soldiers provided effective power, and the religious class provided legitimacy, sustained politics for the remainder of the Muslim Middle Ages and into early modernity. And with the rise of the Ottoman Empire, which successfully reunited the Arab Middle East (with the exception of Morocco and parts of 'Iraq), a political equilibrium was reached between, on the one hand, a powerful executive that could underwrite the security and justice of the territories under its control, and on the other hand, the religious elite, which provided the Empire with effective religious legitimacy by staffing the Empire's courts and civilian bureaucracy. The Ottoman Empire, from the perspective of medieval Islamic political theorists such as al-Ghazali, could very well have been viewed as approximating late medieval Islamic political ideals: effective secular power was joined with religion to produce a stable and powerful polity that in important ways lent effective institutional support to Islamic religious and social ideals as well as implementing a system of public justice that was largely derived from the work of the religious class. Although the Ottoman Empire supplemented Islamic law with its own law - known as the qānūn - it did not claim that its dynastic law was superior to or

35 Mohammad Fadel, "Public Authority (Sulțān) in Islamic Law," in The Oxford International Encyclopedia of Legal History, edited by Stanley N. Katz (Oxford University Press, on line edition, 2009), available at http://www.oxfordreference.com.myaccess.library.utoronto.ca/view/10.1093/acref/9780195134056.001.0001/ac ref-9780195134056-e-663?rskey=zPnxty\&result=1.

36 See Hans Klofer, "Handbuch des islamischen Staats und Verwaltungsrechtes von Badr al-Dīn ibn Ğamā'a," 6 Islamica 349-414 (1934) and 7 Islamica 1-64 (1935); 5 Mughnī al-Muḥtāj, Shams al-Dīn Muḥammad b. Aḥmad alKhațīb al-Shirbīnī (Beirut: Dār al-Kutub al-'Ilmiyya, $1^{\text {st }}$ edition, 1994), edited by 'Alī Muhammad Mu'awwaḍ and 'Ādil Aḥmad 'Abd al-Mawjūd, p. 423.

37 H.A.R. Gibb, "Constitutional Organization," in Law in the Middle East, edited by M. Khadduri and H. Liebesny (Washington, DC: The Middle East Institute, 1955), p. 23 and Noel Coulson, "The State and the Individual in Islamic Law," in The Traditional Near East, edited by J. Stewart Robinson (Englewood Cliffs, NJ: Prentice-Hall, 1966), p. 131. 
intended to supplant the shari'a; moreover, unlike pre-Ottoman dynasties, the Ottomans entrusted ordinary courts with the enforcement of Ottoman qanun, instead of establishing special courts staffed largely (if not exclusively) from the executive/military branch of the state.

The Ottoman constitution's solution to the relationship of state and religion began to break down early in the $19^{\text {th }}$ century, however, when it became increasingly clear that the Ottomans no longer had the ability to provide security against threats from Western Europe and Russia. The external weakness of the Ottomans vis-à-vis Christian powers was also reflected in the various one-sided commercial treaties that the Ottomans entered with European powers throughout the $19^{\text {th }}$ century known as the "Capitulations" - that insulated the nationals of capitulatory powers from the jurisdiction of Ottoman courts and often gave capitulatory powers veto powers over internal Ottoman economic policies. Neither the Ottoman state nor Ottoman civil society, however, greeted these negative developments with equanimity or assumed that decline and defeat was inevitable. The Ottoman state, beginning in the second quarter of the $19^{\text {th }}$ century, launched an ambitious reform project known as the tanzimimāt, "the new order." The new order introduced radical institutional innovation throughout the Ottoman military, civilian and judicial bureaucracies, including, adoption of numerous European legal codes and the creation of new courts to administer them. The new order also introduced new systems of public finance as the Ottomans attempted to place the finances of the Empire on a more secure footing. The Ottomans also embarked on an ambitious project to codify the Hanafi school of Islamic law - the official legal school of the Empire - that produced, upon its completion, the highly-influential multi-volume compilation of Islamic civil law known as al-Majalla. ${ }^{38}$

The radical nature of Ottoman institutional reforms, combined with its conscious emulation of European models of governance and its ever-increasing integration into the European state system, produced a backlash against the reforms, particularly among groups with vested interests in the old institutions. The new order also raised the ire of conservative elements within the religious establishment, and making common cause with other disgruntled interest groups, they accused the new reforms of effectively abandoning the Islamic basis of the state in favor of a European (Christian) conception of the state. Contemporaneously with these institutional reforms, many Ottoman intellectuals, including religious scholars, became prominent defenders not only of the new order, but also of the desirability of the European institutions that Ottoman reforms sought to introduce to the Empire from an Islamic perspective. In making Islamic arguments in favor of the reform, this group of reformers set themselves on a course that challenged the religious establishment, which, for the large part, was either indifferent or hostile to the new order as contrary to Islamic law. ${ }^{39}$

Three nineteenth and early twentieth century thinkers were especially prominent in providing grounds legitimating the new order, and ultimately laying the foundation for an Islamic theory of

38 For a detailed but critical account of the Tanzīmāt as a betrayal of the Islamic tradition, see Hallaq, pp. 401-42. For a more sympathetic account of the legitimacy of the Tanzīmāt, see Fadel, pp. 114-19 and Butrus AbuManneh, "The Islamic Roots of the Gülhane Rescript," 34 Die Welt des Islams 173 (1994).

39 The following account is drawn from Mohammad Fadel, "Modernist Islamic Political Thought and the Egyptian and Tunisian Revolutions of 2011," 3 Middle East Law and Governance 94, 98-104 (2011). 
popular sovereignty in opposition to autocratic politics. These thinkers are the Egyptian, Rafi' Rifā'a alTahțāwī, the Tunisian, Khayr al-Dīn al-Tūnisī, and the Syrian, Rashīd Riḍā. Al-Tahțāwī's career as a public intellectual and advocate of reform began in the wake of a lengthy sojourn in Paris as a religious adviser to a group of Egyptians who had been sent by Muhammad 'Alī, the Ottoman governor of Egypt, to study various modern sciences in Paris. While in Paris, Tahțāwī mastered French, and proved himself to be an avid student of French culture, politics and law. When he returned to Egypt, he published a memoir of his days in Paris in which he discussed in detail and with great approval, the structure of France's constitutional monarchy, and the French commitment to political equality and the rule of law, all of which produced a polity that was capable of upholding justice, promoting prosperity, securing the rights of French citizens and effectively restricting the arbitrary power of the ruler. For Tahțāwī the prosperity of the French state and French citizens was best explained by the justice of its constitution and the rationality of its laws that guaranteed the citizens freedom from arbitrary government interference in their lives.

Tahțāwī's praise of the French polity did not, however, lead him to question his convictions as a Muslim or in the efficacy of Islamic law as the basic law of his civilization. Instead, he argued that the progress he witnessed in France, and by extension all of Europe, was based on Islamic foundations that Europeans were able, through assiduous practice and continual development, to perfect. Accordingly, he called for rulers in Muslim states to commit themselves to a program of legal reform that would provide the same benefits of modern civilization enjoyed by Europeans to the Muslim world. From an ideological perspective, Tahțāwī emphasized that such a reform program needed to be grounded in Islamic revelation (shar') and not human reason ('aq/), even though he argued that from a substantive perspective, both sources lead to substantially the same results. Crucially, Tahțāwī argued that the ruler continued to be bound by the shari'a as articulated by the jurists, meaning, that the state was not entitled to its own interpretations of the shari'a but could only legislate based on norms developed by the jurists themselves. On the other hand, the state was not limited to mandatory norms of the shari'a, but could use its supererogatory norms as a basis for implementing progressive legislation.

The goal of such modern legislation is the moral and material perfection of the homeland, and this requires a practical synthesis between rational and revealed law. But achievement of this goal is not achieved solely through a wise law-giver; it also requires properly motivated subjects of the law who, because of their own moral commitments to the law - and here religion and patriotism mix internalize the law and zealously insure that its norms are upheld, not only against others in society who would violate the rights of their fellow citizens, but also against the arbitrary action of the state.

Khayr al-Dīn al-Tunisī, who was the Prime Minister to the Ottoman governor of Tunisia and then later became the Grand Vizier in Istanbul, also wrote an influential work in which he argued that the reforms instituted by the Ottomans, far from undermining the role of the shari'a, were in fact necessary to restore its effectiveness. Arguing that the relative decay of the Ottoman state was a product of the decline of the rule of law and the concomitant rise of lawlessness, he concluded that the tanzimat were intended to reinvigorate the rule of law in the Ottoman state by instituting greater accountability to the law and creating new institutions that were more responsive to the public good. He directed his criticism to two kinds of critics of the tanzimat. The first argument was directed against those who 
believed that the reforms undermined the shari'a insofar as they altered indigenous Muslim institutions in favor of non-Muslim models of governance. The second argument was directed against those who believed that the ruler's prerogatives to pursue the public good were absolute and public officials, in order to perform their duties effectively, could not be bound by the views of the ruled.

To both groups of critics of the reforms he argued that the prosperity of states is dependent on the rule of law as the essential means to fight arbitrary and despotic rule. The rule of law was satisfied through effective commitments to both revealed law (the shari'a) and rational positive law (qānūn). When the Ottoman state was strong according to Tūnisī, its rulers were effectively bound by both sets of norms, but decay set in when public officials were no longer effectively constrained by either. The tanzimat were simply a species of rational law that were necessary to make the shari'a effective and could not, therefore, be fairly accused of replacing the shari'a with non-Islamic law. But at the same time, making the shari'a effective requires its rules to be formulated in a manner that is responsive to contemporary problems and not in the frozen and static manner found in the medieval treatises that the traditional legal elite spent years mastering in their theo-juridical studies. Making the shari'a effective in the modern era would require collaboration between these juristic elites and modern technocratic elites, with the latter explaining to the former the various policy goals sought to be achieved by modern lawmaking, and the former providing technical advice as to drafting rules in a form that would be consistent with the norms of the shari'a.

Similarly, the prerogatives of public officials had to be limited by law in order to insure that public officials fulfilled their duties. Al-Tūnisĩ argued that there was no dispute in Islamic law that the exercise of discretion was only legitimate if it furthered the public good (al-mașlaha). According to alTūnisī, however, a public official who acts unilaterally and despotically - even if sincerely - was likely to err in his determinations of the public good. The world was simply too complex for a single decision maker to discern the public good consistently without the inputs of others, to say nothing of the risks that despotic decision making poses to the public good when the official is corrupt.

The rule of law, which consists of both rational and revealed norms, is necessary to prevent despotic decision making and increase the likelihood that the decisions of public officials are in fact consistent with the public good. Laws, however, are not self-executing, and they cannot prevent arbitrary rule unless groups of people in society stand ever ready to defend the integrity of the law against those who would violate the law's demands, particularly when those who violate the law are public officials. The challenge of the reformist for al-Tūnisi then was not determination of the content of just law - which by hypothesis included both revealed law and rational law - but rather to establish institutions and produce citizens that wold uphold the ideal of the rule of law against the ever-present risk of despotism. The tanzimat served the institutional demands of the ideal of rule of law: al-Tūnisī stated that parliaments, newspapers, public councils, etc., are all institutions that are necessary to monitor the performance of public officials and ensure that they in fact operate under the rule of law. Religion, more specifically, Islam, supplied the moral, inward force for the vitality of the rule of law: according to al-Tūnisī, a Muslim's religious belief serves as an internal motive (wāzi'), particularly through the Islamic doctrine of commanding the good and prohibiting the evil (al-amr bi'l-ma'rüf wa'l- 
nahy 'an al-munkar), predisposing Muslims to monitor the performance of public officials and hold them accountable for breaches of the law.

Muhammad Rashīd Rị̂ā, the Syrian disciple of the celebrated Egyptian religious reformer Muhammad 'Abduh, writing in the wake of the collapse of the Ottoman Empire following its defeat in World War I, and the decision of Turkish Republic to dissolve the caliphate, called upon Muslims to establish a renewed caliphate dedicated to comprehensive religious, political and moral reform of the Islamic world. For Riḍā, the weakness of the Muslim that made it vulnerable to the domination of Europeans was despotism, political and religious. According to Riḍā, the rulers and religious scholars entered into a compact pursuant to which the latter would not question the decisions of the rulers, and instead counsel the people that their duty was to obey the rulers without fail (except in certain narrow circumstances), even if their policies were contrary to the public good. The quid pro quo for this agreement was that the rulers agreed not to interfere with the teachings of the religious scholars, even if those doctrines were contrary to the public good.

The doctrine of absolute (or virtually absolute) obedience in the political realm was thus coupled with the doctrine of absolute obedience in religious matters, both of which stripped individual Muslims of their individual dignity ( $i z z a$ ) and imposed upon them a regime of servility (dhull) that rendered them incapable of resisting imperialism. Reform required changes to Islamic law so that it was no longer produced solely through the hermeneutical techniques of traditional jurisprudence and instead would be produced through collective deliberations in which the public good (mașlaha) would be more fundamental than fidelity to the text of revelation. Political despotism would be resolved by rejection of the doctrine of an absolute duty of obedience to the ruler in favor of the principle of popular sovereignty, and that all legitimate power came exclusively from the people. Accordingly, Ridāa formulated the notion that Islam required some kind of republican form of government as a prerequisite for the moral and political reform of Muslim society to allow it to escape the domination of external powers. This could not take place, however, until Muslims were liberated from the political despotism of their rulers and the religious despotism of the theologians. Politically, this required a revived caliphate that was based on the actual consent of the community; religiously, this meant liberation of Islamic law from the shackles placed on it by the doctrine of deference - taqlid - and replace it with independent reasoning - ijtihād - in law, derived through a public deliberative process that took into account both revealed and secular sources.

While none of these thinkers advocated a liberal conception of the state, or even necessarily a liberal conception of religion, they were all united in giving the state a greater role in the formulation of religious norms as a means of promoting both the material and the moral progress of the individuals under its rule. Moreover, they all agreed, even if they deployed their arguments in different contexts and for different ends, that reform required the formation of a new kind of Muslim political subjectivity, one that would produce citizens who would be actively involved in public governance, whether through the articulation of political and moral norms, or monitoring public and private behavior to ensure its conformity with the law. All three of them, to different extents, then elevated public political life over the interpretive activities of the religious class which, although not to be dismissed out of hand, were to 
be largely subordinated to what each of them agreed was the key to reform: a morally and politically revitalized state and citizenry. ${ }^{40}$

4. The Divide Between Republican Islam and Authoritarian Islam in Post-Revolutionary Egypt

The religious fissures between traditionalist Islam and modernist reformers described in Section $3^{41}$ continued throughout the twentieth century in Egypt, despite the nationalization by the Egyptian state of the oldest center of religious education in Egypt, the Azhar in $1961 .{ }^{42}$ When al-Azhar re-emerged as an independent institutional actor in the 1970s during the reign of President Sadat, it remained thoroughly committed to a top-down conception of Islam's relationship with the state, arguing that the state was obligated to implement Islamic law without prior democratic deliberation. ${ }^{43}$ The Muslim Brotherhood, while nominally allied with the Azhar insofar as the principle demand of both was the restoration of Islamic law as Egypt's basic law, began halting steps toward embracing democracy in the 1980s, when it agreed to compete in parliamentary elections. ${ }^{44}$ Any tension that existed in the respective approaches of the Azhar and the Muslim Brotherhood, however, was largely irrelevant so long as Egypt was firmly governed by an authoritarian state, and in light of their mutual opposition to the violence of Islamic militants and their mutual commitment to Islamizing Egyptian civil society through preaching. In such circumstances, both the Azhar and the Muslim Brotherhood could pursue their respective agendas without worry about their deeper political disagreements. Divisions on how Islamic law should be implemented, however, could no longer be ignored after the success of the 2011 Revolution, with the Muslim Brotherhood taking the position, even if only for tactical reasons, that the representative institutions of the state should be given the final word in defining the content of Islamic law, while the Azhar strove for recognition that it would serve as the ultimate arbiter of Islam, including the content of Islamic law, in Egypt.

The post-revolutionary battle between the advocates of what I am calling "republican" Islam and "authoritarian" Islam was fought out largely in the media, and while many religious figures were involved in these debates, two figures stand out: Yūsuf al-Qaraḍāwī (b. 1926), as the exemplar of

40 Indira Falk Gesnik, Islamic Reform and Conservativism - al-Azhar and the Evolution of Modern Sunni Islam (New York: I.B. Tauris Publishers, 2010) ("the modernists' vision of lay ijtihad constituted a democratization of religious knowledge that would motivate against arbitrary exercise of power."). p. 234.

41 For a thorough overview of the at times nasty politics that took place between and among the Khedive of Egypt, British officials in Egypt, traditionalist religious scholars suspicious of religious reforms and modernist reformers, see ibid., pp. 165-96.

42 Following the Free Officers' coup in 1952, however, both traditionalist religious figures and reformists suffered at the hands of the military regime, with the regime doing its best to domesticate the Azhar (and largely succeeding, at least throughout the 60s), and to eliminate the Muslim Brotherhood. Malika Zeghal, "Religion and Politics in Egypt: The Ulema of al-Azhar, Radical Islam and the State (1952-94)," 31,3 International Journal of Middle East Studies (1999), pp. 371-99.

43

Ibid., pp. 382-83.

44

See n. 1, supra. 
"republican" Islam, on the one hand, and 'Ali Jumu'a, as the exemplar of "authoritarian" Islam, on the other. Both are Egyptians, but their respective careers took radically different paths as a result of their respective stances toward the Egyptian state. Qaraḍāwī, who grew up in the inter-war era when parts of Egypt were still under British occupation, from early on developed an adversarial stance toward the Egyptian government, and was imprisoned at various times, both by the monarchy and, following the overthrow of King Farūq in 1952, Egypt's military rulers. He left Egypt for Qatar in the early 1960s, not returning again to Egypt until the Egyptian Revolution of 2011. During his lengthy and prolific career, Qaraḍāwī sought to maintain what he called a centrist "wasațī" conception of Islam, one that was neither slavish to inherited historical doctrines, nor one that would secularize Islam and reduce it to private belief. By the time the Egyptian Revolution of 2011 broke out, Qaraḍāwī had become a leading figure of global Islam, a position earned in part as a result of his prolific writings and his weekly satellite TV show al-Sharīa wa'l-Hayāt [Sharīa and Life], which was broadcast throughout the Arab world on the Qatari news station, al-Jazeera. ${ }^{45}$

'Alī Jumu'a, by contrast, pursued a career within the official Egyptian religious establishment, eventually becoming the official Mufti of Egypt when Hosni Mubarak appointed him to that post in 2003. ${ }^{46}$ The Mufti of Egypt is head of the Dār al-Iftā' [Department of Islamic Legal Opinions], a division of the Egyptian Ministry of Justice, which was established by a decree of the Khedive 'Abbās Hilmī in 1895. One of several governmental institutions that represent establishment Islam in Egypt, the Dār alIftā's position inside the Ministry of Justice gives it a more central role than other state religious institutions in the legal articulation of Islam insofar as it is expected to pass on the legality, from an Islamic perspective, of certain actions of the state, particularly, when the state chooses to deploy capital punishment against convicted criminals. ${ }^{47}$

In many respects, it is difficult to find major substantive disagreements between either Qaraḍāwī or Jumu'a on fundamental matters of Islamic law and how it should be applied in the modern world. Both of them, for example, reject an interpretation of Islam that would limit it to a question of

\footnotetext{
45 Western academics have published several works on Qaraḍ̄wī's life and thought. See, for example, Global Mufti: the Phenomenon of Yusuf al-Qaradawi, edited by Jakob Skovgaard-Peterson and Bettina Gräf (London: Hurst \& Co., 2009); Gudrun Krämer, "Drawing Boundaries: Yūsuf al-Qaraḍāwī on Apostasy," in Speaking for Islam: Religious Authorities in Muslim Societies, edited by Gudrun Krämer and Sabine Schmidtke (Boston: Brill, 2006), pp. 181-217 (with a useful biography, pp. 184-200); and, Deina Ali Abdelkader, Islamic Activists: the AntiEnlightenment Democrats (New York: Pluto Press, 2011), pp. 43-65. For an accessible on-line biography of Qaraḍāwī, see Ana Belen Soage, Shaykh Yusuf al-Qaradawi: Portrait of a Leading Islamist Cleric, available at http://www.gloria-center.org/2008/03/soage-2008-03-05/. (last viewed, February 8, 2015).
}

$46 \quad$ 'Alī Jumu'a's life and writings have not been as extensively studied as those of al-Qaraḍawī's. For a basic overview of his life and work, see Heba Raouf Ezzat, "Gumaa, Ali," The Oxford Encyclopedia of the Islamic World.

47 For background on the relationship of the Dār al-Iftā' to the Egyptian state, see Jakob Skovgaard-Petersen, Defining Islam for the Egyptian State: Muftis and Fatwas of the Dār al-Iftā' (New York: Brill, 1997). See also, Peri Bearman, "Dār al-Iftā'," in The Oxford Encyclopedia of Islam and Politics. 
private belief. ${ }^{48}$ Although both of them reject slavish adherence to the historical tradition of Islamic law, neither has much sympathy for those who would cast it out in its entirety. While each believes that the historical tradition of Islamic law should be drawn upon in formulating practical solutions for both individual Muslims and Muslim-majority societies, they do not believe that respect for historical Islamic law precludes adopting new solutions in light of the present circumstances and present needs of the Muslim community. Theologically, both accept an ecumenical understanding of Islam that rejects sectarianism and anathematization of dissident Muslim sects as evidenced by their common adherence to The Amman Message of 2006. ${ }^{49}$ Finally, 'Alī Jumu'a, just like Qaraḍāwī, repeatedly emphasizes the need call people to a centrist conception of Islam (wasațī). ${ }^{50}$

Prior to the Arab Spring, with the durability of Arab authoritarian orders unquestioned, the differences between the two men, and their conceptions of the relationship of religion to state authority, could be, and largely were, ignored. Once the Tunisian fruit vendor, Muhammad Buazizi immolated himself, however, setting off a chain of revolutionary events across the Arab world, the political differences between Qaraḍāwī and establishment representatives of Islam like 'Alĩ Jumu'a were thrown into sharp relief. Qaraḍāwī, for example, while falling short of categorically absolving Al-Buazizi of the sin of suicide, placed responsibility for his actions on the authoritarian regime in Tunisia, and by analogy, condemned the entire Arab state system for producing a generation of youth pushed to the brink of despair. ${ }^{51}$ He also went on to express not only his profound hope that God would forgive Buazizi his transgression, but also declared that Islam provides sufficient lawful means to resist tyranny so that there is no need for Arab youth to resort to suicide instead of agitating for political change. ${ }^{52}$

$48 \quad$ When asked about the relationship of Islam to politics, for example, 'Alī Jumu'a, while denying its role in partisan politics, affirmed that "insofar as politics is concerned with the good order of the community's affairs . . . and because religion is concerned with the good order of the community's affairs, it must be involved in politics from that perspective (al-siyāsa . . . ri 'āyat shu'ūn al-umma . . . wa naẓaran li-'anna al-dīn yar'ā shu'ūn al-umma fahuwa yata 'arrạ̣ li'l-siyāsa min hādhihi al-nāḥiya)." Aḥmad al-Buhairī, 'Alī Jumu 'a Mutafā'il bi-Mustaqbal Mișr wa Lastu Nādiman 'alā Ziyārat al-Quds -- Hiwār ['Alī Jumu'a is Optimistic About Egypt's Future and 'I do not regret visiting Jerusalem' - a Dialogue], al-Masrī al-Yawm, July 1, 2014, available at http://www.almasryalyoum.com/news/details/473719. (Last viewed, February 11, 2015).

49 The principles of The Amman Message were three: mutual recognition of Islamic sects and the prohibition of declaring adherents of these sects to be apostates; affirmation that the disagreements among Muslims is less important than what unites them; and, the impermissibility of issuing legal opinions in the absence of the requisite qualifications or, under the guise of independent interpretation, to issue rulings that contradict well-established principles of Islam that are held by the various historical interpretations of Islam. The Amman Message, available at http://ammanmessage.com/index.php?option=com_content\&task=view\&id=17\&ltemid=31. (Last viewed, February 8, 2015).

50 On 'Alī Jumu'a's substantive interpretations of Islamic law, see Ezzat, supra n. 46. On al-Qaraḍāwī's views regarding modern Islamic law, see Krämer, “Drawing Boundaries,” pp. 197-200, supra n. 45.

51 Al-Shaykh al-Qaraḍāwī wa Ra'yuhu fí'-ntiḥār Muhammad al-Bū'azīzī, available at https://www.youtube.com/watch?v=mJzS1IWJXrl. (last viewed, February 10, 2015).

52 Al-Qaraḍāwī Yuwaḍḍị Mawqifahu min al-Bū 'azīzī [Al-Qaraḍāwī clarifies his stance toward Buazizi], available at 
Arab religious establishments, such as al-Azhar, on the other hand, merely reaffirmed orthodox Islamic teachings that suicide is a grave sin, no matter what the cause, while completely ignoring the underlying political message of Buazizi's suicide. ${ }^{53}$

When the January $25^{\text {th }}$ Revolution broke out in Egypt, the differences between the two men's understanding of politics and religion became even starker, with Qaraḍāwī standing staunchly on the side of the revolutionaries, and 'Ali Jumu'a defending the regime of Hosni Mubarak. ${ }^{54}$ When the July $3^{\text {rd }}$ coup took place, their roles, predictably, were reversed, with 'Alī Jumu'a embracing the June 30 protestors and resurrecting the pre-modern Islamic doctrine that a legitimate ruler who loses his effective power due to a coup or the like ceases to be the legitimate ruler, while Qaraḍāwī insisted that legitimacy in the modern world can only be the result of free and fair elections, not military-supported popular demonstrations. ${ }^{55}$ Indeed, 'Alī Jumu'a not only supported the coup, he also incited the Egyptian military, in a sermon given to the armed forces in the presence of its senior leadership, to kill supporters of the deposed president, urging them to "shoot to kill" (idrab fíl-malyān). ${ }^{56}$

It would be too easy to dismiss 'Alī Jumu'a's pro-military position as simply that of a sycophant or a hypocrite ready to exploit religious doctrine to support his political master, a position that Qaraḍāwī, in his various post-coup polemics against 'Alī Jumu'a, has regularly taken. The more interesting question is why do so many well-known religious scholars who are part of the religious

http://www.aljazeera.net/news/arabic/2011/1/19/\%D8\%A7\%D9\%84\%D9\%82\%D8\%B1\%D8\%B6\%D8\%A7\%D9\%88\% D9\%8A-\%D9\%8A\%D9\%88\%D8\%B6\%D8\%AD-\%D9\%85\%D9\%88\%D9\%82\%D9\%81\%D9\%87-\%D9\%85\%D9\%86\%D8\%A7\%D9\%84\%D8\%A8\%D9\%88\%D8\%B9\%D8\%B2\%D9\%8A\%D8\%B2\%D9\%8A. (last viewed, February 10, 2015).

53 Al-Azhar li-muqallidi al-bū 'azīzī: al-Islām yuharrim al-intihạar li-ayyi sabab [Al-Azhar to those imitating Buazizi: 'Islam prohibits suicide for any reason'], available at http://www.onislam.net/arabic/newsanalysis/newsreports/islamic-world/127961-2011-01-18-21-41-07.html. (last viewed, February 9, 2015).

54 Yūsuf al-Qaraḍ̄wīi, Rudūd 'Ilmiyya 'alā al-Shaykh aw al-Janirāl 'Alī Jumu'a [Scholarly Replies to the Shaykh or "General" 'Alī Jumu'a], September 18, 2013, available at http://www.qaradawi.net/new/articles/6844-2013-0902-15-08-03 . (Last viewed, February 10, 2015). Recordings of some of his pro-Mubarak statements are available on YouTube, for example, Al-Muftī 'Alī Jumu 'a Athnā' Thawrat 25 Yanāyir Yuqaddim Tahiyya li-Mubārak wa Yuharrim al-Khurūj 'alayhi [The Mufti 'Alī Jumu'a During the January $25^{\text {th }}$ Revolution Saluting Mubarak and Declaring the Sinfulness of Opposing Him], available at https://www.youtube.com/watch?v=IFjg0pKk5qA. (Last viewed, February 10, 2015).

55 Scholarly Replies; and, Yūsuf al-Qaraḍ̄āī, Radd 'alā Muftī al-'Askar [A Reply to the Mufti of the Armed Forces], October 11, 2013, available at http://www.qaradawi.net/new/articles/6891-2013-10-09-21-00-30. (Last viewed, February 10, 2015).

56 Reply to the Mufti; see also, Video Musarrab Li- 'Alī Jumu 'a li-I-Sīsī fĩ Huḍūr al-Sīsī 'Iḍrab fï'l-Malyān' [A Smuggled Video of 'Alī Jumu'a in the Presence of al-Sīsī 'Shoot to Kill'], https://www.youtube.com/watch?v=NJzPVAQQEXc. (last seen, February 10, 2015). In this video, 'Alī Jumu'a exhorts the armed forces to cleanse Egypt of the former president's supporters, even claiming that the army's position was vindicated by, among other things, the "innumerable visions (tawātarat al-ru'ā) of the Prophet of God" that came to Egypt's living saints in which he communicated to them his support for the military against the former president. 
establishment in various Muslim countries consistently oppose democratization, even when, in the case of the Muslim Brotherhood, there was no attempt to remove them from their positions as interpreters of a state-supported religion? While it would be speculative to claim that the politics of 'Ali Jumu'a and other traditionalist scholars who support authoritarian orders in the Muslim world is a direct result of their adherence to the political philosophy articulated by medieval theologians such as al-Ghazâli, they share a certain political aesthetic with al-Ghazālī which assumes that a hierarchical order which unifies symbolic (religious) authority and coercive power is necessary for the maintenance of social and religious unity.

Accordingly, 'Alī Jumu'a, in various interviews published in Egyptian newspapers, stresses the need for national unity as a precondition for progress. ${ }^{57}$ In another interview, he expressed his view that "freedom means adhering to [proper] authority and legitimacy, not escaping [from them] and following capricious whims or desires." ${ }^{58}$ What is most dangerous to national unity, in the opinion of 'Ali Jumu'a and other traditionalists, however, is religious division, which they dismiss as "chaos in religious discourse (fawḍa al-khițāb al-dīnî)." One of greatest accomplishments of the January $25^{\text {th }}$ Revolution was the birth of a robust public sphere in which Egyptian citizens of all stripes were free to express their views on a broad range of topics, including religion, that for the previous fifty years had been subject to strict state control. Religion was one of the fields which had suddenly become open to a radical pluralism that establishmentarian theologians such as 'Alī Jumu'a found deeply troubling. Instead of taking robust public discussion about religious affairs as evidence of a people deeply committed to a deeper self-understanding of religion and its relationship to their lives, establishment theologians took the extent of public religious debate - and the disagreement it necessarily produced - as something threatening to the existence of religion:

"Q. 'Recently, non-specialists have given many religious opinions (fatāwā) which have produced much contention (jadal) and confusion (balbala) in society. What is your opinion about that?"”

"A. 'We refer to this condition as "chaos in religious discourse (faw ḍa fíl khițāb aldini I)", and it is the result of [the actions of] some individuals who are only expressing their personal views, not [the views of] official establishments (jiha rasmiyya). They

$57 \quad$ When asked by the interviewer how Egypt is to survive the transitional period safely, he replied "By means of agreement and keeping far from disagreements ('an țarīq al-ittifāq wa'l-bu'd 'an al-khilāf)." Ibrāhīm 'Imrān, al-Duktūr 'Alī Jumu'a: Fawḍā al-Khitāb al-Dīnī wa'l-Furqa wa'l-Tanāḥur bayna Abnā' al-Wațan Abraz alTahaddiyyāt Amām al-Muftī al-Jadīd [Dr. 'Alī Jumu'a: Chaotic Religious Discourse and Division and Conflict Among the People Are the Gravest Challenges Facing the New Muftī], al-Ahrām, February 28, 2013, available at http://www.ahram.org.eg/NewsQ/133883.aspx. (Last viewed, February 11, 2015). Jumu'a's suspicion of disagreement and contention as destructive of national unity echoed concerns of religious conservatives of the $19^{\text {th }}$ century who feared that calls from religious reformers to abandon traditional legal doctrines in favor of rules derived from renewed independent interpretations of Islamic law would undermine established beliefs and practices of the community and undermine the community's unity. Gesnik, pp. 179-80.

58 “Inna al-ḥurriyya ta'nī al-iltizām bi'l-marja iyya wa'l-shar iyya wa lā ta'nī al-tafallut wa'ttibā' al-ahwā'." 'Alī Jumu'a Mutafā'il bi-Mustaqbal Mișr, supra n. 48. 
have created chaos in religious discourse. You might come across one of them speaking about religion, and you are surprised to find yourself in front of a zealot (mutashaddid), then go to another, and find him licentious (mutasayyib). You might then go to a third and he is moderate (wasațan) or a fourth who reduces religion to spiritual matters (rūhāniyyāt) or a fifth who reduces religion to politics (siyāsa), and so on and so forth. This produces a general condition among the people of confusion and contention as a result of the numerous religious controversies emerging from religious discourse. ${ }^{159}$

Nor was 'Ali Jumu'a the only establishmentarian theologian in Egypt to express fears about the subversive consequences of religious pluralism in Egyptian society. Shaykh 'Abd al-Hamīd al-Ațrash, for example, complained that "the people have become confused and contentious as a consequence of differences of opinion." 60 'Alī Jumu'a, at a speech delivered at Singapore's Nanyang Technological University on June 10, 2014, even blamed the rise of religious extremism in the Muslim world on the problem of the breakdown of religious authority and the concomitant spread of pluralistic religious interpretations at the hands of unqualified religious autodidacts:

"['Alĩ Jumu'a] continued, saying that 'Among the problems that confront the modern world is the problem of authority. In Islam and also other religions, we are witnessing the phenomenon of non-specialists who lack sufficient religious education but who nevertheless hold themselves out as religious authorities, despite the fact that they lack the preparation that would enable them to speak about Islamic law (alsharīa) and morality ( $a k h l \bar{a} q)$. This tendency has cast the door wide open for extremist interpretations of Islam which have no foundation. The reality is that none of these extremists have studied Islam in any recognized center of Islamic learning. Rather, they [and their interpretations] are only the product of social conditions brimming with problems. They have relied on perverted and distorted interpretations [of religion] and they seek to spread chaos.' He went on to insist that 'Our role as an Islamic religious leadership which has spent its entire life studying religious texts is to restore [religious] authority by returning those who have solid foundations of learning (qadam rāsikha fi'l-'ilm) [to their rightful position].'”61

$59 \quad$ Ibid.

60 "Al-nās taḥayyarat wa tabalbalat min ikhtilāf al-ārā'." Walīd 'Abd al-Raḥmān, Mișr: Șaḥwa Azhariyya li'lhadd min Fawḍā al-Fatwā [The Azhar Awakens to Place a Limit on the Chaos of Religious Opinion], al-Sharq alAwsaț, September 11, 2012, available at http://archive.aawsat.com/details.asp?section=17\&article=694740\&issueno=12341\#.VNyMMPnF8d8. (Last viewed, February 12, 2015).

61 Ziyād Mujāhid, Alī Jumu'a 'Ghayr al-Mutakhașșișin Yunașșibūna Anfusahum Marji ìyyāt Dīniyya li-lthārat al-Fawḍā' ['Ali Jumu'a 'Non-Specialists Are Making Themselves Religious Authorities to Spread Chaos'], AlBawwāba, June 10, 2014, available at http://www.albawabhnews.com/628139. (Last viewed, February 12, 2015). 
In light of establishment theologians' fears of religious pluralism as a source of political instability and religious disorder, it is unsurprising that they demanded that the state put an end to the perceived crisis in religion stemming from the pluralism of the post-Mubarak period. Accordingly, they asked the state to pass a law that would, among other things, criminalize the public dissemination of religious opinions unless the person giving the opinion was part of an official institution. ${ }^{62}$ When a journalist from the Ahram, the flagship newspaper of the state, asked 'Alī Jumu'a for his opinion whether some laws were needed to limit the communication of religious opinions using mass media to those who have been given special licenses granted to them by the Azhar, he replied that in light of the gravity of the function of giving religious opinions, "it is necessary that this matter should be restricted to specialized scholars, and that scholars who wish to assume this position be trained thoroughly so that they possess the requisite qualifications for this grave task." ${ }^{\prime 33}$ Al-Qaraḍāwī's writings also are cognizant of the danger of religious extremism that emerged in a context where enthusiasm surpassed learning. Unlike his establishmentarian colleagues, however, he took the view that what was needed to prevent extremism was tarshīd, guidance, not suppression. ${ }^{64}$ As he explained in his essay, al-Fiqh fi Marātib alAhkām wa Adab al-Khilāf [Jurisprudence in [Light of the Definitiveness of] Legal Rulings], the proper antidote to both fanatic attachment to religious opinion and to confusion that may arise in the mind of the laity when faced with numerous opinions on the same question of religious law was to educate them about the role of interpretation in determining the content of Islamic law, and that differences of opinion on the detailed questions of Islamic law are both inevitable and enriching to the community, not contrary to its unity or the interests of Muslims. ${ }^{65}$

5. The Muslim Brotherhood and Establishment Islam in Egypt

The previous discussion highlights the anxiety that establishment theologians experienced when they witnessed the wave of religious pluralism that broke out as a result of the breakdown of Mubarak's authoritarian order. While these theologians do not explicitly name the Muslim Brotherhood as the party responsible for the "chaos in religious discourse" affecting Egypt and other Muslim societies, it is clear that they believe that the Brotherhood's approach to religion and religious renewal, with its populist focus, is a big part of the problem, and most definitely not part of the solution. Because the Muslim Brotherhood was perceived as a political actor using religion for its own partisan political

62 Saḥwa Azhariyya, supra n. 60 ("țālaba 'ulamā’ azhariyyūn fĩ mișr al-sulțāt al-mișriyya bi-qānūn yujarrim fawọā al-fatāwā . . . wa akkadū anna 'al-azhar ḥasama amr jihat al-fatwā wa manaḥa dār al-iftā' al-ḥaqq al-wahīd fï ișdār al-fatwā fíl-bilād (Azharī scholars in Egypt have demanded that the Egyptian authorities promulgate a law criminalizing the chaos in religious opinions . . . and they also affirmed that the Azhar has resolved the issue of where religious opinions are to be obtained, and gave the Dar al-Iftā' the exclusive right to issue religious opinions in the country.)").

63 Fawḍā al-Khitāb al-Dīnī, supra n. 57 (lā budda min qașr al-amr 'alā al-mutakhașșișina min al- 'ulamā' li'liftā’ min khilāl al-ma āyīr allatī yanbaghī an tatawaffara fĩ man yatașaddar li-hādhihi al-muhimma al- 'aẓīma).

64 Krämer, “Drawing Boundaries,” pp. 199-200, supra n. 45.

65 Yūsuf al-Qaraḍ̄āī, al-Fiqh fi Marātib al-Ahkām wa Adab al-Khilāf, available at http://qaradawi.net/new/library2/291-2014-01-26-18-54-35/3959- (last viewed, November 29, 2015). 
interests (their opponents often contemptuously referred to them as tujjār al-dīn ("merchants of religion")), establishment theologians worried that opposition to the Muslim Brotherhood as a political party would translate into opposition to religion as such. ${ }^{66}$ Just as worrisome, however, must have been the fact that the Muslim Brotherhood had its own hierarchical structure of religious authority that was independent of the established religious institutions of the Egyptian state. And despite the hue and cry over various provisions in the Egyptian constitution of 2012 that secular critics claimed would empower the Azhar to exercise a supervisory role over state legislation, the Muslim Brotherhood was largely indifferent to the constitutional role of the Azhar in the Egyptian state because "it controlled the presidency and looked forward to a strong parliamentary role.... [I]t was happy to pursue Islamization of the Egyptian legal order slowly - by legislation, for instance." ${ }^{67}$

The Muslim Brotherhood's preference for the democratically expressed will of the people as an equally (if not more) legitimate interpretation of Islamic law manifested itself in an obscure controversy that took place during the brief term of President Morsi when there was an attempt to pass a law authorizing the state to issue bonds that were in compliance with Islamic law, known as șukūk. The government of Egypt, because of its financial crisis, was desperate to attract foreign capital. One previously untapped source of funding had been Islamic finance, and although numerous jurisdictions and private companies had tapped the Islamic finance market in the decade preceding the Egyptian Revolution of 2011, Egypt had not. One reason that Egypt had not sought to raise funds from this sector was that the government had not promulgated a law that would enable it to issue such bonds which, because of their non-conventional, asset-backed structure, required special legislation. The proposed law intended to remedy this problem.

Islamic finance, including șukūk, however, is not free of controversy, with many Muslims critical of these instruments as being subterfuges intended to circumvent the Islamic prohibition on interestbearing loans. At the time the law was proposed, the 2012 Constitution had been approved, but the House of Representatives, Majlis al-Nuwwāb, had not yet been elected, it having been dissolved earlier in the year by the Supreme Constitutional Court. As a result, only the second chamber of the Parliament, the Majlis al-Shürā, was in session. For reasons not relevant here, the Muslim Brotherhood and the more theologically conservative Salafi Nūr Party dominated membership of this chamber, but the Muslim Brotherhood's Freedom and Justice Party held the majority of seats. The proposed Șukūk law troubled the minority Salafis insofar as they believed it was an illegitimate attempt to circumvent Islamic law's prohibition on the payment of interest. They lacked sufficient votes in the Majlis al-Shūrā to block

66 For example, the Egyptian Minister of Religious Endowments, has justified his Ministry's attempt to exercise direct control over all of Egypt's mosques in the wake of the coup partially on the ground that in the polarized political atmosphere, political debates degenerate into incitements to violence and apostasy. Ahmed Morsi and Nathan Brown, "Egypt's al-Azhar Steps Forward," Carnegie Endowment for International Peace, Nov. 7, 2013, available at http://carnegieendowment.org/2013/11/07/egypt-s-al-azhar-steps-forward\#. (Last viewed, February 14, 2015).

$67 \quad N a t h a n$ Brown and Clark Lombardi, “Islam in Egypt's New Constitution," Foreign Policy, Dec. 13, 2012, available at http://foreignpolicy.com/2012/12/13/islam-in-egypts-new-constitution/?wp_login_redirect=0. (Last viewed, February 14, 2015). 
the law, however, so they invoked Article 4 of the new constitution which provided that the Council of Senior Scholars of Azhar should be consulted on matters related to Islamic law in an attempt to block or modify the proposed law. ${ }^{68}$

The response of 'Ișām al-'Aryān, representative of the majority Freedom and Justice Party, the political wing of the Muslim Brotherhood, could not have been reassuring to the religious establishment. Despite language in the 2012 Constitution which provided that "the opinion of the Senior Council of Scholars of Azhar is taken [into account] in matters connected to Islamic law,"69 al-'Aryān stated that this provision, in fact, did not make the Azhar the exclusive or final adjudicator on the law's conformity with Islamic teachings. Rather, the provision merely authorized the parliament, in its capacity as sole lawmaker, or the justices of the Supreme Constitutional Court, in its capacity as supervisor of the constitutionality of legislation, to consult with Azhar's senior scholars when each body is exercising its constitutionally delegated functions, namely law-making, in the case of parliament, and judicial review, in the case of the Supreme Constitutional Court. In each case, however, it was the right, not the duty, of these bodies to consult with the Azhar, a right that could only be exercised when a majority of each body chooses to solicit the opinion of the Azhar on the matter that is under debate. ${ }^{70}$ President Morsi, in response to political pressure from the Salafis and demands from al-Azhar, however, eventually relented, and sent the bill to the Council of the Senior Scholars of Azhar for their review, ${ }^{71}$ and in their first review of the draft, they rejected it. ${ }^{72}$

68 Ibid. For an overview of the debate that took place in the Majlis al-Shūrā, see Aḥmad Sāmī Mutawallī et al., Jadal bi'l-Shūrā Hawl Musammā Qānūn al-Șukūk wa 'Adam 'Arọihī 'alā Kibār al- 'Ulamā'; al-'Aryān: al-Barlamān Yakhtașș bi'l-Tashrī' wa'l-Dustūriyya Turāqib al-Qawānīn [Debate Around the Nomenclature in the Șukūk Law and Whether it Should be Reviewed by the Councils of Senior Scholars [of Azhar]; al-'Aryān: Parliament is Responsible for Making Laws and the Supreme Constitutional Court Supervises Whether They are Constitutional], al-Ahrām, March 8, 2013, available at http://www.ahram.org.eg/NewsQ/137308.aspx. (Last viewed, February 14, 2015).

$69 \quad$ Art. 4, Egyptian Constitution of 2012, available at http://www.constitutionnet.org/files/final_dreaft_of_constitution_as_of_30_nov_2012.pdf (Arabic, last viewed, February 14, 2015). An English translation is available at http://www.constitutionnet.org/files/final_constitution_30_nov_2012_-english-_-idea.pdf. (Last viewed, February 14, 2015).

70 "Al-Radd 'alā al-Kadhdhābīn Alladhīna Yaqūlūna Inna al-Azhar Huwa Man Kāna Yufassir al-Sharīa fi Dustūr 2012 [A Reply to the Liars Who Say That the Azhar Had the Authority to Interpret Islamic Law in the 2012 Constitution], available at https://www.youtube.com/watch?v=m7Nui4dIQmU. (Last viewed, February 14, 2015) ('Ișām al-'Aryān giving a speech in the Majlis al-Shūrā denying the obligation to submit proposed legislation to the Azhar for review to assure its conformity with Islamic law, and affirming that all powers exercised by the government come from the Egyptian people).

71 Mursī Yuhīl Mashrū al-Ṣukūk al-Islāmiyya ilā al-Azhar li-lbdā' al-Ra’y fîhi [Morsi Refers the Islamic Bonds Bill to the Azhar so that It May Give its Opinion], IIāf, April 2, 2013, available at http://elaph.com/Web/news/2013/3/802758.html (last viewed, November 29, 2015).

72 Hay'at Kibār al- 'Ulamā' Tarfuḍ Mashrū'al-Șukūk [Council of Senior Scholars of Azhar Rejects the Islamic Bonds Bill], Muhammad 'Abd al-Shakūr and Mahmud Fayid, al-Wafd, April 11, 2013, available at 
Whether or not the Muslim religious establishment chose to support the coup was a result of a simple calculation based on the balance of power, or a principled opposition to the politicization of religious debate and the increase in religious divisions as a result, it is indisputable that the Azhar, as a religious institution, emerged much more powerful in the wake of the coup than it was in the Islamic republican model being developed by the Muslim Brotherhood. ${ }^{73}$ The de facto power of the Azhar as the religious authority for Muslims in Egypt was rendered de jure by the 2013 Constitution. Article 7 of the amended constitution, while it removed any reference to a role for the Senior Council of Azhar Scholars in lawmaking, recognized the Azhar as the "primary authority (al-marji 'al-asāsī)" for the articulation and supervision of Islam in Egypt. As a result of the coup, then, the Muslim religious establishment emerged not only with institutional independence from the state, but also what could reasonably be viewed as the exclusive legal authority for the teaching and supervision of Islam in Egypt. $^{74}$

\section{Conclusion}

From a liberal perspective, it is tempting to view constitutional battles in Egypt from the perspective western history, a history that was characterized by a battle between the powerful institutions of the Catholic Church, on the one hand, and European monarchs, on the other hand. A simplistic attempt to apply this model of religion-state relations to the Arab world is not likely to cast much light on the actual dynamics of the current struggle taking place insofar as there is no religious institution in the Arab world that plays a political role that would be comparable to that played by the Catholic Church in European political history. Instead, one is witnessing a different kind of battle taking place, one in which the question is how religion should be incorporated in the state and practiced in society: should it be subject to a state monopoly, or should a religiously pluralistic public sphere be tolerated, one which would include not only "moderate" conceptions of religion which are consistent with state policies, but also "radical" or "extremist" conceptions of religion which challenge the state's religious message, whether from within a religious discourse that finds the state's religious policies too lax, for example, or from an atheistic perspective that rejects religion altogether and finds the state's attempts to promulgate a state-sanctioned version of religious orthodoxy oppressive. ${ }^{75}$

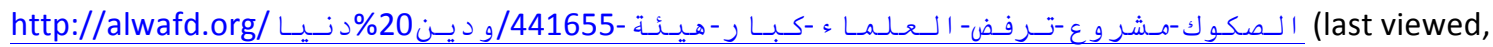
November 29, 2015).

73 Al-Azhar Steps Forward, supra n. 27 ("al-Azhar is now leading Egypt's religious establishment into a new era. Traditional rival institutions have been brought into far tighter coordination, and the grand sheikh and the Council of Senior Scholars stand at the head of the more unified apparatus.).

74 Al-Azhar al-Sharīf . . al-Marji' al-Asāsī fïl-'Ulūm al-Dīniyya wa'l-Shu'ūn al-Islāmiyya ("The Noble Azhar is the primary authority for religious learning and Islamic affairs."). Art. 7, Egyptian Constitution of 2013, available at http://www.constitutionnet.org/files/final_constitution_-2_dec_2013-arabic-_signed.pdf. (Last viewed, February 14, 2015). An English translation is available at http://www.constitutionnet.org/files/dustor-en001.pdf. (Last viewed, February 14, 2015).

75 One of the ironies of the coup has been that the new President of Egypt has, in addition to outlawing the Muslim Brotherhood and declaring it a terrorist organization, has launched a very public campaign confronting the 
While the Muslim Brotherhood is certainly not a liberal movement, its conception of religion and its role in politics is tolerant - even if grudgingly - of pluralism in the religious public sphere. This practical toleration, even if born of necessity and not principle, produced, for the first time in recent Egyptian history, a genuinely pluralistic public sphere in which religious topics could be freely debated in public and in an arguably civil spirit. ${ }^{76}$ In the language of Jeffry Stout, the January $25^{\text {th }}$ Revolution produced, even if for only a relatively brief period of time, a substantially more secularized, but not secular, public space in Egypt. ${ }^{77}$ In a secularized public space, appeals to religious arguments decline not because the citizens necessarily lose religious faith, but as a result of the combination of the increasingly pluralistic theologies of citizens themselves, and the increasing realization that religious arguments, because of their malleability, are inconclusive for political purposes. In response, citizens resort to other, non-theological, rhetorical strategies in attempts to forge broader agreement, not because they have suddenly become non-believers, but rather because they realize that they can no longer assume deep agreement on theological principles. Something akin to this process was clearly taking place in post-Mubarak Egypt, and Egypt's Muslim religious establishment (and probably its Coptic counterpart as well) found these developments quite dangerous. Their support of a military coup was likely motivated by a desire to put an end to the increasing secularization of the religious public square that took place following the Jan. $25^{\text {th }}$ Revolution, a phenomenon that the political ascendancy of the Muslim Brotherhood only served to accelerate, and that the continued existence of competitive politics would only further entrench as different conceptions of religion and the state would be articulated in the course of political competition.

From the perspective of the pre-modern Islamic tradition, the state was supposed to protect both religious orthodoxy and act in a representative capacity. In modern circumstances, however, it cannot act in a representative fashion without weakening its commitment to the protection of religious orthodoxy. While advocates of republican Islam such as al-Qaraḍāwī do not seem to be overly fearful of the spread of heterodoxy in the wake of democratization, traditionalist theologians such as 'Ali Jumu'a

"threat" of atheism. See, for example, Mona Eltahawy, "Egypt's War on Atheism," Jan. 27, 2015, N.Y. Times, available at http://www.nytimes.com/2015/01/28/opinion/mona-eltahawy-egypts-war-on-atheism.html?_r=0 (last viewed, February 15, 2015); Louisa Loveluck, “Egypt's Sisi Urges Religious Moderation, But No Space for Insulting Images," Jan. 14, 2015, Christian Science Monitor, available at http://www.csmonitor.com/World/MiddleEast/2015/0114/Egypt-s-Sisi-urges-religious-moderation-but-no-space-for-insulting-images (last viewed, February 15, 2015); Brian Whitaker, "Sisi's Egypt to Eliminate Atheism," June 19, 2014, albab.com, available at http://www.al-bab.com/blog/2014/may-june/egypt-to-eliminate-atheism.htm\#sthash.AZIDvDPu.8RUyMIn8.dpbs (last viewed, February 15, 2015); Marwa Morgan, "Sisi's Quest to Maintain 'Moral Discipline' Returning Egypt to Authoritarianism," Jan. 12, 2015, Alakhbar English, available at http://english.al-akhbar.com/node/23169 (last viewed, February 15, 2015); and Sarah Lynch, "In Egypt, Atheists Considered a 'Dangerous' Development," USA Today, Feb. 2, 2015, available at http://www.religionnews.com/2015/02/02/egypt-atheists-considered-dangerousdevelopment/ (last viewed, February 15, 2015).

76 Kristin Deasy, “Debating Atheism in the Heart of Cairo," Feb. 21, 2013, World Affairs Millennial Letters, available at http://www.worldaffairsjournal.org/blog/kristin-deasy/debating-atheism-heart-cairo (last viewed, February 15, 2015) (describing public meetings debating theism, atheism and Islam held in a mosque in downtown Cairo). 
have clearly decided that protection of religious orthodoxy is more important than establishing a representative government. In making this choice, they are clearly vindicating a well-established line of reasoning in Islamic political thought. The Muslim religious establishment of Egypt believes that in Sisi it has found the pious autocrat idealized by pre-modern Muslim theologians such as al-Ghazali, and from their perspective, a religious autocrat who can control religious debate is preferable to a religious president presiding over a political system in which religious teachings become a subject of public contestation. Whether, however, this strategy can provide long-term political and theological stability for Egypt and other Muslim-majority countries, is questionable. For the foreseeable future, however, the future looks bleak for any kind of republican Islam to become ascendant in Egypt, and it is the turn of the religious establishment to try to create a stable resolution to the problem of state-religion relations in the Arab world. 